\title{
Upaya Meningkatkan Mutu Pembelajaran Melalui Supervisi Akademik Dengan Tehnik Kunjungan Kelas Di SDN 1 Kopang Semester Ganjil Tahun Pelajaran 2019/2020
}

\author{
Ahmad \\ Pengawas SD Kecamatan Kopang Kabupaten Lombok Tengah
}

\begin{abstract}
Abstrak. Hasil pengamatan di SDN 1 Kopang Guru cenderung pasif dalam melengkapi Administrasi Pembelajaran. Untuk Administrasi pembelajaran rata-rata yang diperoleh Guru kelas maupun guru Mata Pelajaran sebelum dilakukannya penelitian rata-ratanya adalah 60,46. dan persentase jumlah guru yang mencapai standar sebesar $54,55 \%$ Nilai ini sangatlah jauh dari persentase guru yang memiliki Administrasi pembelajaran yang ditetapkan di SD 1 Kopang, yaitu sebesar 90\%. Penelitian tindakan Sekolah (PTS) ini dilaksanakan selama 3 bulan (Juli s.d September 2019) dengan menggunakan metode Kunjungan Kelas dalam upaya meningkatkan mutu pembelajaran di SDN 1 Kopang Semester Ganjil Tahun Pelajaran 209/2020. Penelitian dilaksanakan dalam dua siklus masing-masing terdiri dari dua pertemuan melalui tahapan-tahapan sebagai berikut perencanaan, tindakan obervasi dan refleksi. Teknik pengumpulan data dilakukan melalui lembar pengamatan oleh observer untuk melihat data tentang aktivitas belajar dan mengajar, sementara data tentang hasil supervisi diperoleh melalui pengamatan dan Observasi di kelas pada siklus 1, dan disiklus 2. Hasil yang diperoleh dari Penelitian Tindakan Sekolah (PTS) melalui model metode Kunjungan Kelas memperlihatkan rata-rata dalam penyusunan administrasi mengajar sebesar 20,15\% meningkat pada siklus II menjadi 80,66
\end{abstract}

\section{Kata kunci : Metode Kunjungan Kelas, Supervisi Akademik, Mutu Pembelajaran}

\section{PENDAHULUAN}

\section{Latar Belakang Masalah}

Pada hakekatnya bahwa pembelajaran dapat terlaksana apabila terdapat interkasi antar guru dengan murid serta sarana pendukung pembelajaran, dan salah satunya penentu keberhasilan pada kegiatan belajar mengajar adalah guru, jika seorang guru malas mengajar dan enggan membuat perangkat pembelajaran, maka apa yang terjadi pada hasil pendidikan, tiada lain siswa akan malas pula belajar. Berdasarkan kenyataan tersebut dalam meningkatkan mutu pendidikan di sekolah maka dibutuhkan adanya supervisi yang profesional yang mampu membimbing, menjadi teladan, dan mampu menggerakkan guru dalam peningkatan mutu pendidikan di sekolah.

Dengan demikian, berarti, esensi supervisi akademik itu sama sekali bukan menilai kinerja guru dalam mengelola proses pembelajaran, melainkan membantu guru mengembangkan kemampuan profesionalismenya. Meskipun demikian, supervisi akademik tidak bisa terlepas dari penilaian unjuk kerja guru dalam mengelola pembelajaran.

Guru dituntut mampu memahami makna dan karakter kurikurikulum sehingga dapat menguasai materi, metoda, teknik, evaluasi pembelajaran sehingga hasil pembelajaran pada suatu satuan pendidikan dapat dicapai secara maksimal dan bermutu.

Peraturan pemerintah No 10 tahun 2005 bab I pasal 1 ayat 6 bahwa standar proses pendidikan adalah standar nasional yang berkaitan dengan pelaksanaan pembelajaran pada satuan pendidikan untuk mencapai suatu standar kompetensi lulusan

Berdasarkan uraian di atas penulis tertarik untuk melakukan Penelitian Tindakan Sekolah (PTS) yang berjudul "Upaya Meningkatkan Mutu Pembelajaran Melalui Supervisi Akademik dengan Tehnik Kunjungan Kelas di SDN 1 Kopang Semester Ganjil Tahun Pelajaran 2019/2020"

\section{Identifikasi Masalah}

Penyusunan karya tulis harus sesuai dengan kondisi nyata kegiatan yang dilakukan para guru di SDN 1 Kopang. Masalah yang 
terkait dengan judul Penelitian Tindakan Sekolah ini sangat luas dan kompleks. Untuk memperoleh hasil yang diharapkan penulis terfokus pada kajian masalah yang dikaitkan dengan kondisi nyata dan paparan proses pembelajaran oleh para guru.

Berdasarkan latar belakang masalah yang telah diuraikan maka masalah yang muncul dapat diidentifikasi oleh penulis sebagai berikut :

1. Rendahnya minat belajar siswa, dibuktikan dengan hasil nilai ulangan harian kurang memenuhi KKM/KBM.

2. Hanya $15 \%$ siswa mempunyai minat belajar tinggi, dibuktikan dengan jumlah pengunjung perpustakaan rata-rata 70 s.d. 80 siswa/hari

3. Hanya $35 \%$ siswa mempunyai minat belajar sedang, dibuktikan dengan jumlah siswa yang mengumpulkan tugas praktek/kokurikuler kurang dari setengah jumlah siswa per kelas.

4. Hanya $50 \%$ siswa mempunyai minat belajar rendah

\section{Pembatasan Masalah}

Berdasarkan keempat masalah yang teridentifikasi di atas, maka penulis membatasi masalah pada Proses pembelajaran guru kurang memberi semangat pada siswa untuk mencintai mata pelajaran.

1. Kualitas pembelajaran yang dilakukan guru kurang memberi motivasi siswa dalam semangat belajarnya.

2. Peran supervisi akademik sangat besar dalam menghasilkan proses pembelajaran yang bermutu.

\section{Rumusan Masalah}

Berdasarkan latar belakang masalah yang penulis rumuskan di atas, penulis menetapkan beberapa rumusan masalah antara lain :

1. Apakah dengan supervisi akademik bagi guru dapat meningkatkan kinerjanya?,

2. Apakah dengan supervisi akademik dapat merubah minat kemauan melaksanakan pembelajaran yang baik sesuai dengan aturan dan langkah-langkah proses belajar mengajar?,

3. Apakah dengan supervisi ini dapat merubah budaya belajar di kelas menjadi membaik dengan pola belajar yang aktif, kreatif, efektif dan menyenangkan?

\section{Tujuan Penelitian}

Suatu kegiatan mustahil dilakukan jika tanpa ada tujuan. Begitu pun dengan penelitian ini, dilakukan dengan tujuan :

1. Meningkatkan mutu pembelajaran siswa SDN 1 Kopang

2. Meningkatkan minat belajar siswa SDN 1 Kopang

3. Meningkatkan kemampuan guru dalam pelaksanaan pembelajaran sehingga sesuai dengan standar yang telah ditetapkan.

\section{Manfaat Penelitian}

Manfaat penelitian supervisi akademik adalah untuk merubah paradigma lama sistem pembelajaran yang Datang Duduk Catat dan Hafal (DDCH) menjadi model pembelajaran yang aktif, kreatif, efektif dan menyenangkan. Penelitian ini diharapkan dapat memberikan manfaat:

Bagi kepala sekolah

a. Dapat meningkatkan profesionalisme supervisi untuk meningkatkan efektifitas proses belajar mengajar di SDN 1 Kopang Kecamatan Kopang

b. Dapat meningkatkan kinerja sekolah melalui peningkatan profesionalisme guru.

Bagi Guru

a. Dapat meningkatkan kemampuan guru mengefektifkan proses belajar mengajar di kelas melalui sepervisi pelaksanaan pembelajaran.

b. Dapat memberikan pengertian pada guru bahwa supervisi merupakan tugas kepala sekolah sehingga bukan merupakan suatu hal yang luar biasa, akhirnya guru diharapkan dapat disupervisi setiap saat dan bahkan guru mengajukan supervisi klinis kepada kepala sekolah.

c. Memberikan motivasi pada guru untuk mengefektifkan proses belajar mengajar di kelas.

Bagi Siswa

a. Memperoleh pengalaman belajar yang lebih menarik.

b. Meningkatkan aktivitas siswa di dalam belajar.

c. Meningkatkan penguasaan konsep. 

d. Menumbuhkan
keberanian
mengemukakan pendapat dalam
kelompok/ membiasakan bekerja sama dengan teman

Bagi Pengembangan ilmu praktis

Dapat memberikan sumbangan kepada pengembangan ilmu praktis di dunia pendidikan tentang pentingnya supervisi pelaksanaan pembelajaran untuk meningkatkan kemampuan guru mengefektifkan proses belajar mengajar di kelas.

\section{KAJIAN TEORI}

\section{Pengertian Guru, Minat, dan Belajar}

Secara etimologi, istilah "Guru" berasal dari bahasa India yang artinya "orang yang mengajarkan tentang kelepa san dari sengsara" Shambuan, Republika, (dalam Suparlan 2005:11). Kemudian Rabindranath Tagore (dalam Suparlan 2005:11) menggunakan istilah Shanti Niketan atau rumah damai untuk tempat para guru mengamalkan tugas mulianya membangun spiritualitas anak-anak bangsa di India (spiritual intelligence).

Pengertian guru kemudian menjadi semakin luas, tidak hanya terbatas dalam kegiatan keilmuan yang bersifat kecerdasan spiritual (spiritual intelligence) dan kecerdasan intelektual (intellectual intelligence), tetapi juga menyangkut kecerdasan kinestetik jasmaniah (bodily kinesthetic), seperti guru tari, guru olah raga, guru senam dan guru musik. Dengan demikian, guru dapat diartikan sebagai orang yang tugasnya terkait dengan upaya mencerdaskan kehidupan bangsa dalam semua aspeknya, baik spiritual dan emosional, intelektual, fisikal, maupun aspek lainnya. Poerwadarminta (dalam Suparlan 2005:13) menyatakan, "guru adalah orang yang kerjanya mengajar." Dengan definisi ini, guru disamakan dengan pengajar. Pengertian guru ini hanya menyebutkan satu sisi yaitu sebagai pengajar, tidak termasuk pengertian guru sebagai pendidik dan pelatih. Selanjutnya Zakiyah Daradjat (dalam Suparlan 2005:13) menyatakan, "guru adalah pendidik profesional karena guru telah menerima dan memikul beban dari orang tua untuk ikut mendidik anak-anak."
UU Guru dan Dosen Republik Indonesia No.14 Tahun 2005 "Guru adalah pendidik profesional dengan tugas utama mendidik, mengajar, membimbing, mengarahkan, melatih, menilai, dan mengevaluasi peserta didik pada pendidikan anak usia dini jalur pendidikan formal, pendidikan dasar, dan pendidikan menengah".

Selanjutnya UU No.20 Tahun 2003 pasal 39 ayat 2 tentang sistem pendidikan nasional menyatakan, "pendidik merupakan tenaga profesional yang bertugas merencanakan dan melaksanakan proses pembelajaran, menilai hasil pembelajaran, melakukan pembimbingan dan pelatihan, serta melakukan penelitian dan pengabdian kepada masyarakat, terutama bagi pendidik pada perguruan tinggi." PP No.19 Tahun 2005 tentang Standar Nasional Pendidikan menyatakan, "pendidik (guru) harus memiliki kualifikasi akademik dan kompetensi sebagai agen pembelajaran, sehat jasmani dan rohani, serta memiliki kemampuan untuk mewujudkan tujuan pendidikan nasional." Berdasarkan definisi di atas, dapat disimpulkan bahwa guru adalah tenaga pendidik yang profesional dengan tugas utama mendidik, mengajar, membimbing, mengarahkan, melatih, menilai dan mengevaluasi peserta didik, dan bertugas merencanakan dan melaksanakan proses pembelajaran.

Minat belajar terdiri dari dua kata yakni minat dan belajar, dua kata ini beda arti, untuk itu penulis akan mendefinisikan satu persatu, sebagai berikut:

a. Minat menurut kamus besar bahasa Indonesia adalah kecenderungan hati yang tinggi terhadap suatu gairah keinginan.

b. Minat menurut Mahfudz Shalahuddin adalah perhatian yang mengandung unsur-unsur perasaan.

c. Minat menurut Crow dan Crow, minat atau interest bisa berhubungan dengan daya gerak yang mendorong kita cenderung atau merasa tertarik pada orang, benda dan kegiatan.

Berdasarkan definisi-definisi di atas, bisa disimpulkan bahwa minat adalah kecenderungan jiwa yang relative menetap 
pada diri seseorang dan biasanya disertai dengan perasaan senang. Menurut Berhard "minat" timbul atau muncul tidak secara tibatiba melainkan timbul akibat dari partisipasi, pengalaman, kebiasaan pada waktu belajar atau bekerja, dengan kata lain minat dapat menjadi penyebab kegiatan dan partisipasi dalam kegiatan. Sedangkan pengertian belajar adalah sebagai berikut:

a. Belajar menurut Ernest $\mathrm{R}$ Hicgard adalah proses perbuatan yang dengan sengaja bisa menimbulkan perubahan, yang keadaannya berbeda dari perubahan yang ditumbulkan sebelumnya.

b. Menurut Gagne, belajar merupakan perubahan yang diperlihatkan dalam bentuk tingkah laku, yang keadaannya berbeda dari sebelum individu berada dalam situasi belajar dan sesudah melakukan tindakan yang sempurna itu.

c. Menurut Sardiman, belajar merupakan usaha penguasaan materi ilmu pengetahuan yang merupakan sebagian kegiatan menuju terbentuknya kepribadian seutuhnya.

Dari definisi-definisi di atas, dapat ditarik kesimpulan bahwa belajar itu menimbulkan suatu perubahan tingkah laku yang relatif tetap dan dilakukan lewat kegiatan, atau usaha yang disengaja.

Jadi, yang dimaksud dari minat belajar adalah aspek psikologi seseorang yang menampakkan diri dalam beberapa gejala,seperti : gairah, keinginan, perasaan suka untuk melakukan proses perubahan tingkah laku melalui berbagai kegiatan yang meliputi mencari pengetahuan dan pengalaman, dengan kata lain minat belajar itu adalah perhatian, rasa suka, ketertarikan seseorang (siswa) terhadap belajar yang ditunjukkan melalui keantusiasan, partisipasi, dan keaktifan dalam belajar.

Komunikasi persuasif adalah komunikasi yang bertujuan untuk mengubah atau mempengaruhi kepercayaan, sikap, dan perilaku seseorang sehingga bertindak sesuai dengan apa yang diharapkan oleh komunikator.
Pada umumnya sikap-sikap individu/ kelompok yang hendak dipengaruhi ini terdiri dari tiga komponen:

1. Kognitif - perilaku dimana individu mencapai tingkat "tahu" pada objek yang diperkenalkan.

2. Afektif - perilaku dimana individu mempunyai kecenderungan untuk suka atau tidak suka pada objek.

3. Konatif - perilaku yang sudah sampai tahap hingga individu melakukan sesuatu (perbuatan) terhadap objek.

\section{Standar Kompetensi Guru}

Depdiknas (2004:4) kompetensi diartikan, "sebagai pengetahuan, keterampilan, dan nilai-nilai dasar yang direfleksikan dalam kebiasaan berpikir dan bertindak". "Secara sederhana kompetensi diartikan seperangkat kemampuan yang meliputi pengetahuan, sikap, nilai dan keterampilan yang harus dikuasai dan dimiliki seseorang dalam rangka melaksanakan tugas pokok, fungsi dan tanggung jawab pekerjaan dan/atau jabatan yang disandangnya" (Nana Sudjana 2009:1).

Nurhadi (2004:15) menyatakan, "kompetensi merupakan pengetahuan, keterampilan, dan nilai-nilai dasar yang direfleksikan dalam kebiasaan berpikir dan bertindak". Selanjutnya menurut para ahli pendidikan McAshan (dalam Nurhadi 2004:16) menyatakan, "kompetensi diartikan sebagai pengetahuan, keterampilan, dan kemampuan yang dikuasai seseorang sebagai pengetahuan, keterampilan, dan kemampuan yang dikuasai seseorang yang telah menjadi bagian dari dirinya, sehingga dapat melakukan perilaku-perilaku koqnitif, afektif, dan psikomotor dengan sebaik-baiknya."

Kompetensi diartikan sebagai pengetahuan, keterampilan, dan nilai-nilai dasar yang direfleksikan dalam kebiasaan berfikir dan bertindak (Dalam Suparlan). Arti lain dari kompetensi adalah spesifikasi dari pengetahuan, keterampilan, dan sikap yang dimiliki seseorang serta penerapannya di dalam pekerjaan, sesuai dengan standar kinerja yang dibutuhkan oleh lapangan.

Berdasarkan pendapat di atas dapat disimpulkan kompetensi adalah sebagai suatu kecakapan untuk melakukan sesuatu 
pekerjaan berkat pengetahuan, keterampilan ataupun keahlian yang dimiliki untuk melaksanakan suatu pekerjaan.

Undang-Undang Guru dan Dosan No.14 Tahun 2005 Pasal 8 menyatakan, " guru wajib memiliki kualifikasi akademik, kompetensi, sertifikat pendidik, sehat jasmani dan rohani, serta memiliki kemampuan untuk mewujudkan tujuan pendidikan nasional." Dari rumusan di atas jelas disebutkan pemilikan kompetensi oleh setiap guru merupakan syarat yang mutlak harus dipenuhi oleh guru. Dengan demikian, kompetensi yang dimiliki oleh setiap guru akan menunjukkan kualitas guru yang sebenarnya.

Selanjutnya Pasal 10 menyebutkan empat kompetensi yang harus dimiliki oleh guru yakni (1) kompetensi pedagogik , (2) kompetensi kepribadian, (3) kompetensi sosial, dan (4) kompetensi profesional. Kompetensi tersebut akan terwujud dalam bentuk penguasaan pengetahuan, keterampilan, maupun sikap profesional dalam menjalankan fungsi sebagai guru.

Berdasarkan beberapa definisi di atas dapat disimpulkan standar Kompetensi guru adalah suatu pernyataan tentang kriteria yang dipersyaratkan, ditetapkan dalam bentuk penguasaan perangkat kemampuan yang meliputi pengetahuan, sikap, nilai dan keterampilan bagi seorang tenaga kependidikan sehingga layak disebut kompeten. Standar kompetensi guru dipilah ke dalam tiga komponen yang kaitmengait, yakni: 1) pengelolaan pembelajar an, 2) pengembangan profesi, dan 3) penguasaan akademik. Komponen pertama terdiri atas empat kompetensi, komponen kedua memiliki satu kompetensi, dan komponen ketiga memiliki dua kompetensi. Dengan demikian, ketiga komponen tersebut secara keseluruhan meliputi $\mathrm{t}$ ujuh kompetensi dasar, yaitu: 1) penyusunan rencana pembelajaran, 2) pelaksanaan interaksi belajar mengajar, 3) penilaian prestasi belajar peserta didik, 4) pelaksanaan tindak lanjut hasil penilaian prestasi belajar peserta didik, pengembangan profesi, 6) pemahaman wa wasan kependidikan, dan 7) penguasaan bahan kajian akademik ( sesuai dengan mata pelajaran yang diajarkan).

Abdurrahman Mas'ud (dalam Suparlan 2005:99) menyebutkan tiga kompetensi dasar yang harus dimiliki guru, yakni: (1) menguasai materi atau bahan ajar, (2) antusiasme, dan ( 3) penuh kasih sayang (loving) dalam mengajar dan mendidik.

\section{Supervisi akademik}

Supervisi akademik adalah serangkaian kegiatan membantu guru mengembangkan kemampuannya mengelola proses pembelajaran demi pencapaian tujuan pembelajaran Akhmad Sudrajat (1981). Sementara itu, M. Ngalimin PUrwanto (1989) menyebutkan bahwa supervisi akademik merupakan upaya membantu guru-guru mengembangkan kemampuannya mencapai tujuan pembelajaran. Dengan demikian, esensi supervisi akademik itu sama sekali bukan menilai unjuk kerja guru dalam mengelola proses pembelajaran, melainkan membantu guru mengembangkan kemampuan profesionalismenya. Meskipun demikian, supervisi akademik tidak bisa terlepas dari penilaian unjuk kerja guru dalam mengelola pembelajaran. Apabila di atas dikatakan, bahwa supervisi akademik merupakan serangkaian kegiatan membantu guru mengembangkan kemampuannya mengelola proses pembelajaran, maka menilai unjuk kerja guru dalam mengelola proses pembelajaran merupakan salah satu kegiatan yang tidak bisa dihindarkan prosesnya (Sergiovanni, 1987). Penilaian unjuk kerja guru dalam mengelola proses pembelajaran sebagai suatu proses pemberian estimasi kualitas unjuk kerja guru dalam mengelola proses pembelajaran, merupakan bagian integral dari serangkaian kegiatan supervisi akademik. Apabila dikatakan bahwa supervisi akademik merupakan serangkaian kegiatan membantu guru mengembangkan kemampuannya, maka dalam pelaksanaannya terlebih dahulu perlu diadakan penilaian kemampuan guru, sehingga bisa ditetapkan aspek yang perlu dikembangkan dan cara mengembangkannya. 
Sergiovanni (1987) menegaskan bahwa refleksi praktis penilaian unjuk kerja guru dalam supervisi akademik adalah melihat realita kondisi untuk menjawab pertanyaanpertanyaan, misalnya: Apa yang sebenarnya terjadi di dalam kelas? Apa yang sebenarnya dilakukan oleh guru dan murid-murid di dalam kelas? Aktivitas-aktivitas mana dari keseluruhan aktivitas di dalam kelas itu yang berarti bagi guru dan murid? Apa yang telah dilakukan oleh guru dalam mencapai tujuan akademik? Apa kelebihan dan kekurangan guru dan bagaimana cara mengembangkannya?. Berdasarkan jawaban terhadap pertanyaan-pertanyaan ini akan diperoleh informasi mengenai kemampuan guru dalam mengelola kegiatan pembelajaran. Namun satu hal yang perlu ditegaskan di sini, bahwa setelah melakukan penilaian unjuk kerja guru tidak berarti selesailah tugas atau kegiatan supervisi akademik, melainkan harus dilanjutkan dengan perancangan dan pelaksanaan pengembangan kemampuannya. Dengan demikian, melalui supervisi akademik guru akan semakin mampu memfasilitasi belajar bagi murid-muridnya. Alfonso, Firth, dan Neville (1981) menegaskan "Instructional supervision is here in defined as: behavior officially designed by the organization that directly affects teacher behavior in such a way to facilitate pupil learning and achieve the goals of organization”.

Menurut Alfonso, Firth, dan Neville, ada tiga konsep pokok (kunci) dalam pengertian supervisi akademik.

1. Supervisi akademik harus secara langsung mempengaruhi dan mengembangkan perilaku guru dalam mengelola proses pembelajaran. Inilah karakteristik esensial supervisi akademik. Sehubungan dengan ini, janganlah diasumsikan secara sempit, bahwa hanya ada satu cara terbaik yang bisa diaplikasikan dalam semua kegiatan pengembangan perilaku guru. Tidak ada satupun perilaku supervisi akademik yang baik dan cocok bagi semua guru (Glickman, 1981). Tegasnya, tingkat kemampuan, kebutuhan, minat, dan kematangan profesional serta karakteristik personal guru lainnya harus dijadikan dasar pertimbangan dalam mengembangkan dan mengimplementasikan program supervisi akademik (M. Ngalimin Purwanto,)

2. Perilaku supervisor dalam membantu guru mengembangkan kemampuannya harus didesain secara ofisial, sehingga jelas waktu mulai dan berakhirnya program pengembangan tersebut. Desain tersebut terwujud dalam bentuk program supervisi akademik yang mengarah pada tujuan tertentu. Oleh karena supervisi akademik merupakan tanggung jawab bersama antara supervisor dan guru, maka alangkah baik jika programnya didesain bersama oleh supervisor dan guru.

3. Tujuan akhir supervisi akademik adalah agar guru semakin mampu memfasilitasi belajar bagi muridmuridnya.

Selain tersebut di atas, berikut ini ada beberapa prinsip lain yang harus diperhatikan dan direalisasikan oleh supervisor dalam melaksanakan supervisi akademik, yaitu:

1. Supervisi akademik harus mampu menciptakan hubungan kemanusiaan yang harmonis. Hubungan kemanusiaan yang harus diciptakan harus bersifat terbuka, kesetiakawanan, dan informal. Hubungan demikian ini bukan saja antara supervisor dengan guru, melainkan juga antara super- visor dengan pihak lain yang terkait dengan program supervisi akademik. Oleh sebab itu, dalam pelaksanaannya supervisor harus memiliki sifat-sifat, seperti sikap membantu, memahami, terbuka, jujur, ajeg, sabar, antusias, dan penuh humor (Surya Darma, 1972).

2. Supervisi akademik harus dilakukan secara berkesinambungan. Supervisi akademik bukan tugas bersifat sambilan yang hanya dilakukan sewaktu-waktu jika ada kesempatan. Perlu dipahami bahwa supervisi 
akademik merupakan salah satu essential function dalam keseluruhan program sekolah (Sudrajat 1981 dan Made Pidarta 1973). Apabila guru telah berhasil mengembangkan dirinya tidaklah berarti selesailah tugas supervisor, melainkan harus tetap dibina secara berkesinambungan. Hal ini logis, mengingat problema proses pembelajaran selalu muncul dan berkembang.

3. Supervisi akademik harus demokratis. Supervisor tidak boleh mendominasi pelaksanaan supervisi akademiknya. Titik tekan supervisi akademik yang demokratis adalah aktif dan kooperatif. Supervisor harus melibatkan secara aktif guru yang dibinanya. Tanggung jawab perbaikan program akademik bukan hanya pada supervisor melainkan juga pada guru. Oleh sebab itu, program supervisi akademik sebaiknya direncana- kan, dikembangkan dan dilaksanakan bersama secara kooperatif dengan guru, kepala sekolah, dan pihak lain yang terkait di bawah koordinasi supervisor.

4. Program supervisi akademik harus integral dengan program pendidikan. Di dalam setiap organisasi pendidikan terdapat bermacam-macam sistem perilaku dengan tujuan sama, yaitu tujuan pendidikan. Sistem perilaku tersebut antara lain berupa sistem perilaku administratif, sistem perilaku akademik, sistem perilaku kesiswaan, sistem perilaku pengembangan konseling, sistem perilaku supervisi akademik (Alfonso, dkk., 1981). Antara satu sistem dengan sistem lainnya harus dilaksanakan secara integral. Dengan demikian, maka program supervisi akademik integral dengan program pendidikan secara keseluruhan. Dalam upaya perwujudan prinsip ini diperlukan hubungan yang baik dan harmonis antara supervisor dengan semua pihak pelaksana program pendidikan (Dodd, 1972).
5. Supervisi akademik harus komprehensif. Program supervisi akademik harus mencakup keseluruhan aspek pengembangan akademik, walaupun mungkin saja ada penekanan pada aspek-aspek tertentu berdasarkan hasil analisis kebutuhan pengembangan akademik sebelumnya. Prinsip ini tiada lain hanyalah untuk memenuhi tuntutan multi tujuan supervisi akademik, berupa pengawasan kualitas, pengembangan profesional, dan memotivasi guru.

6. Supervisi akademik harus konstruktif. Supervisi akademik bukanlah sekalikali untuk mencari kesalahankesalahan guru. Memang dalam proses pelaksanaan supervisi akademik itu terdapat kegiatan penilaian unjuk kerjan guru, tetapi tujuannya bukan untuk mencari kesalahankesalahannya. Supervisi akademik akan mengembangkan pertumbuhan dan kreativitas guru dalam memahami dan memecahkan problem-problem akademik yang dihadapi.

7. Supervisi akademik harus obyektif. Dalam menyusun, melaksanakan, dan mengevaluasi, keberhasilan program supervisi akademik harus obyektif. Objectivitas dalam penyusunan program berarti bahwa program supervisi akademik itu harus disusun berdasarkan kebutuhan nyata pengembangan profesional guru. Begitu pula dalam mengevaluasi keberhasilan program supervisi akademik. Di sinilah letak pentingnya instrumen pengukuran yang memiliki validitas dan reliabilitas yang tinggi untuk mengukur seberapa kemampuan guru dalam mengelola proses pembelajaran.

Supervisi akademik yang baik harus mampu membuat guru semakin kompeten, yaitu guru semakin menguasai kompetensi, baik kompetensi kepribadian, kompetensi pedagogik, kompetensi profesional, dan kompetensi sosial. Oleh karena itu, supervisi akademik harus menyentuh pada pengembangan seluruh kompetensi 
guru. Menurut Neagley (1980) terdapat dua aspek yang harus menjadi perhatian supervisi akademik baik dalam perencanaannya, pelaksanaannya, maupun penilaiannya.

Pertama, apa yang disebut dengan substantive aspects of professional development (yang selanjutnya akan disebut dengan aspek substantif). Aspek ini menunjuk pada kompetensi guru yang harus dikembangkan melalui supervisi akademik. Aspek ini menunjuk pada kompetensi yang harus dikuasai guru. Penguasaannya merupakan sokongan terhadap keberhasilannya mengelola proses pembelajaran. Ada empat kompetensi guru yang harus dikembangkan melalui supervisi akademik, yaitu yaitu kompetensi-kompetensi kepribadian, pedagogik, professional, dan sosial. Aspek substansi pertama dan kedua merepresentasikan nilai, keyakinan, dan teori yang dipegang oleh guru tentang hakikat pengetahuan, bagaimana murid-murid belajar, penciptaan hubungan guru dan murid, dan faktor lainnya. Aspek ketiga berkaitan dengan seberapa luas pengetahuan guru tentang materi atau bahan pelajaran pada bidang studi yang diajarkannya.

Kedua, apa yang disebut dengan professional development competency areas (yang selanjutnya akan disebut dengan aspek kompetensi). Aspek ini menunjuk pada luasnya setiap aspek substansi. Guru tidak berbeda dengan kasus profesional lainnya. Ia harus mengetahui bagaimana mengerjakan (know how to do) tugas-tugasnya. Ia harus memiliki pengetahuan tentang bagaimana merumuskan tujuan akademik, muridmuridnya, materi pelajaran, dan teknik akademik. Tetapi, mengetahui dan memahami keempat aspek substansi ini belumlah cukup. Seorang guru harus mampu menerapkan pengetahuan dan pemahamannya. Dengan kata lain, ia harus bisa mengerjakan (can do). Selanjutnya, seorang guru harus mau mengerjakan (will do) tugas-tugas berdasarkan kemampuan yang dimilikinya. Percumalah pengetahuan dan keterampilan yang dimiliki oleh seorang guru, apabila ia tidak mau mengerjakan tugas-tugasnya dengan sebaik-baiknya. Akhirnya seorang guru harus mau mengembangkan (will grow) kemampuan dirinya sendiri.

\section{Tehnik Kunjungan Kelas}

Kunjungan Kelas

Kunjungan kelas adalah teknik pembinaan guru oleh kepala sekolah, pengawas, dan Pembina lainnya dalam rangka mengamati pelaksanaan proses belajar mengajar, sehingga memperoleh data yang diperlukan dalam rangka pembinaan guru. Tujuan kunjungan kelas ini adalah untuk menolong guru dalam mengatasi kesulitan atau masalah guru di dalam kelas. Melalui kunjungan kelas, pengawas akan membantu permasalahan yang dialaminya.kunjungan kelas dapat dilakukan dengan pemberitahuan atau tanpa oemberitahuan terlebih dahulu, dan bias juga atas dasar undangan dari guru itu sendiri. Dalam melaksanakan kunjungan kelas, terdapat empat tahap, yaitu

1) Tahap persiapan, Pada tahap ini, pengawas merencanakan waktu, sasaran, dan cara mengobservasi selama kunjungan kelas.

2) Tahap pengamatan, yaitu mengamati jalannya proses pembelajaran berlangsung.

3) Tahap akhir kunjungan, pada tahap akhir ini pengawas bersama guru mengadakan perjanjian untuk membicarakan hasil-hasil observasi, setelah itu dilakukan tindak lanjut.

Ada beberapa criteria kunjungan kelas yang baik, yaitu;

1) Memiliki tujuan-tujuan tertentu.

2) Mengungkapkan aspek-aspek yang dapat memperbaiki kemampuan guru.

3) Menggunakan instrument observasi tertentu untuk mendapatkan daya yang obyektif.

4) Terjadi interaksi antara Pembina dan yang dibina sehingga menimbulkan saling pengertian.

5) Pelaksanaan kunjungan kelas tidak menganggu proses belajar mengajar.

6) Pelaksanaannya diikuti dengan program tindak lanjut.

\section{Observasi Kelas}

Observasi kelas secara sederhana dapat diartikan melihat dan memperhatikan secara teliti terhadap gejala yang tampak. Observasi 
kelas adalah teknik observasi yang dilakukan oleh supervisor terhadap proses pembelajaran yang sedang berlangsung. Tujuannya adalah untuk memperoleh data seobyektif mungkin mengenai aspek-aspek dalam situasi belajar mengajar, kesulitan-kesulitan yang dihadapi oleh guru dalam usaha memperbaiki proses belajar mengajar. Secara umum yang diamati selama proses pembelajaran adalah:

1) Usaha-usaha dan aktivitas guru-siswa dalam proses pembelajaran.

2) Cara penggunaan media pengajaran.

3) Reaksi mental para siswa dalam proses belajar mengajar.

4) Keadaan media pengajaran yang dipakai dari segi materialnya.

Dalam pelaksanaan observasi kelas dilakukan beberapa tahap, yaitu:

1) Persiapan observasi kelas.

2) Pelaksanaan observasi kelas.

3) Penutupan pelaksanaan observasi kelas.

4) Penilaian hasil observasi.

5) Tindak lanjut. Ketika supervisor/pengawas melaksanakan observasi kelas, sebaiknya menggunakan instrument observasi tertentu, antara lain evaluative check-list, activity check-list.

\section{Pertemuan Individual}

Pertemuan individual adalah satu pertemuan, percakapan, dialog, dan tukar pikiran antara Pembina atau supervisor guru, guru dengan guru, mengenai usaha meningkatkan kemampuan professional guru. Tujuannya adalah: (1) memberikan kemungkinan pertumbuhan jabatan guru melalui pemecahan masalah yang dihadapi; (2) mengembangkan hal mengajar yang lebih baik; (3) memperbaiki segala kelemahan dan kekurangan pada diri sendiri; dan (4) menghilangkan atau menghindari segala prasangka yang bukan-bukan.

\section{Kunjungan Antar Kelas}

Kunjungan antarkelas dapat juga digolongkan sebagai teknik supervisi secara perorangan. Kegiatan ini dilakukan guru yang satu berkunjung ke kelas yang lain dalam lingkungan sekolah itu sendiri. Melalui kunjungan antarkelas ini diharapkan guru akan memperoleh pengalaman baru dari teman sejawatnya mengenai pelaksanaan proses pembelajaran, pengelolaan kelas, dan sebagainya. Agar kunjungan antarkelas ini dapat berhasil dengan baik dan bermanfaat, maka harus ada beberapa hal yang diperhatikan antara lain:

1) Guru-guru yang akan dikunjungi harus diseleksi dengan sebaik-baiknya. Diupayakan agar mencari guru yang berpengalaman sehingga mampu memberikan pengalaman baru bagi guru-guru yang akan mengunjungi.

2) Tentukan guru-guru yang akan mengunjungi.

3) Sediakan segala fasilitas yang diperlukan dalam kunjungan kelas.

4) Supervisor/pengawas hendaknya mengikuti acara ini denbgan cermat. Amatilah apa-apa yang ditampilakn secara cermat, dan mencatatnya pada format-format tertentu.

5) Adakan tindak lanjut setelah kunjungan antarkelas selesai. Missal, dengan percakapan pribadi, penegasan, dan pemberian tugas-tugas tertentu.

6) Segera aplikasikan ke sekolah atau ke kelas guru bersangkutan, yaitu dengan menyesuaikan pada situasi dan kondisi yang dihadapi.

7) Adakan perjanjian-perjanjian untuk mengadakan kunjungan antar kelas berikutnya.

\section{Menilai diri Sendiri}

Menilai diri sendiri merupakan satu teknik individual dalam supervisi pendidikan. Penilaian diri sendiri memberikan informasi secara obyektif kepada guru tentang peranannya di kelas dan memberikan kesempatan kepada guru mempelajari metode pengajarannya dalam mempengaruhi murid. Dengan demikian guru akan terdorong untuk mengembangkan diri secara professional. Ada beberapa cara /alat untuk menilai diri sendiri yaitu:

1) Buat suatu pandangan atau pendapat yang disampaikan kepada murid-murid untuk menilai pekerjaan atau suatu aktivitas (buat dalam bentuk pertanyaan bias pertanyaan tertutup atau terbuka dan tidak perlu menyebut nama). 
2) Menganalisis tes-tes terhadap unit kerja.

3) Mencatat murid-murid dalam suatu catatan, baik mereka bekerja secara perorangan maupun secara kelompok.

\section{METODE PENELITIAN}

\section{Subyek, Lokasi, dan Waktu Penelitian}

Subjek yang akan di supervisi adalah guru di SDN 1 Kopang, adapun sasaran utama dilakukannya supervisi akademik SDN 1 Kopang adalah untuk menguji kemampuankemampuan guru dalam merencanakan kegiatan pembelajaran, melaksanakan kegiatan pembelajaran, menilai hasil pembelajaran, memanfaatkan hasil penilaian untuk peningkatan layanan pembelajaran, menciptakan lingkungan belajar yang menyenangkan, memanfaatkan sumber belajar yang tersedia, dan mengembangkan interaksi pembelajaran (strategi, metode, teknik) yang tepat. Supervisi edukatif juga harus didukung oleh instrumen-instrumen yang sesuai

a. Subyek penelitian

Subyek pada penelitian ini adalah guru SDN 1 Kopang, yang terdiri dari 8 orang guru pegawai negeri sipil dan 8 orang guru tidak tetap.

b. Lokasi Penelitian

Penelitian ini penulis lakukan di SDN

1 Kopang Kabupaten Kopang yang berlokasi di Jl. Lapangan Banteng Jelojok Kopang Kabupaten Lombok Tengah

c. Waktu Penelitian

Dalam penelitian ini penulis melakukan selama 3 bulan yaitu bulan Juli s/d September 2019

\section{Prosedur Penelitian}

Penelitian ini berbentuk Penelitian Tindakan Sekolah (School Action Research), yaitu sebuah penelitian yang merupakan kerjasama antara peneliti Kepala Sekolah dan guru,

meningkatkan kemampuan guru agar menjadi lebih baik dalam menyusun proses pembelajaran. Metode yang digunakan dalam penelitian ini adalah metode deskriptif, dengan menggunakan teknik persentase untuk melihat peningkatan yang terjadi dari siklus ke siklus. Metode deskriptif dapat diartikan sebagai prosedur pemecahan masalah yang diselidiki dengan menggambarkan/ melukiskan keadaan subjek penelitian seseorang, lembaga, masyarakat, dan lainlain) pada saat sekarang berdasarkan faktafakta yang tampak atau sebagaimana adanya (Nawawi, 1985:63). Dengan metode ini peneliti berupaya menjelaskan data yang dikumpulkan melalui komunikasi langsung atau

wawancara, observasi/pengamatan, dan disk usi yang berupa persentase atau angka-angka.

Penelitian ini bertujuan untuk mendeskripsikan kesulitan-kesulitan yang dialami oleh guru dalam proses pembelajaran. Selanjutnya peneliti memberikan alternatif atau usaha guna meningkatkan kemampuan guru dalam membuat proses pembelajaran yang bermutu

Hal-hal penting yang harus diperhatikan dalam Penelitian Tindakan Sekolah, menurut Sudarsono, F.X, (1999:2) yakni:

\section{Rencana}

Tindakan apa yang akan dilakukan untuk meningkatkan kompetensi guru dalam menyusun perencanaan pembelajaran. Solusinya yaitu dengan melakukan : a) wawancara dengan guru dengan menyiapkan lembar wawancara, b) Diskusi dalam suasana yang menyenangkan dan c) memberikan bimbingan dalam menyusun proses pembelajaran

\section{Pelaksanaan}

Apa yang dilakukan oleh peneliti sebagai upaya meningkatkan kompetensi guru dalam perencanaan pembelajaran yaitu dengan memberikan bimbingan berkelanjutan pada guru.

\section{Observasi}

Peneliti melakukan pengamatan terhadap perencanaa pembelajaran untuk memotret seberapa jauh kemampuan guru dalam mengevaluasi program, proses, dan hasil pembelajaran. Selain itu juga peneliti mencatat hal-hal yang terjadi dalam pertemuan dan wawancara. Rekaman dari pertemuan dan wawancara akan digunakan untuk analisis dan komentar kemudian.

\section{Refleksi}

Peneliti mengkaji, melihat, dan mempertimbangkan hasil atau dampak dari 
tindakan yang telah dilakukan. Berdasarkan hasil dari refleksi ini, peneliti bersama guru melaksanakan revisi atau perbaikan terhadap kegiatan proses pembelajaran.

Prosedur penelitian adalah suatu rangkaian tahap-tahap penelitian dari awal sampai akhir. Penelitian ini merupakan proses pengkajian sistem berdaur sebagaimana kerangka berpikir yang dikembangkan oleh Suharsimi Arikunto dkk. Prosedur ini mencakup tahap-tahap: (1) perencanaan, (2) pelaksanaan, (3) pengamatan, dan (4) refleksi. Keempat kegiatan tersebut saling terkait dan secara urut membentuk sebuah siklus. Penelitian Tindakan Sekolah merupakan penelitian yang bersiklus, artinya penelitian dilakukan secara berulang dan berkelanjutan sampai tujuan penelitian dapat tercapai." Alur PTS dapat dilihat pada Gambar berikut :

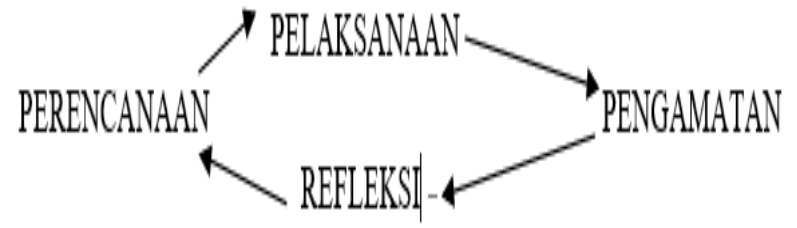

\section{Teknik Pengumpulan Data}

Teknik pengumpulan data dilakukan dengan dokumentasi berupa hasil karya penyusunan administrasi mengajar, wawancara dan instrument analisis penilaian. Perencanaan Tindakan Pelaksanaan Tindakan Pengamatan (observasi)

\section{Teknik Analisis Data}

Data dianalisis menggunakan analisis deskriptif persentase, yakni membandingkan persentase jumlah guru yang membuat administrasi mengajar dan perencanaan pembelajaran, seperti : 1) Peningkatan pembuatan administrasi mengajar yang dilakukan oleh guru minimal $75 \%, 2$ ) Peningkatan perencanaan pembelajaran melalui supervisi akademik yang dilakukan oleh guru minimal $80 \%$, 3) Pembelajaran yang bermutu yang ditandai dengan tingkat keaktifan siswa dalam belajar di atas $75 \%$

\section{HASILDAN PEMBAHASAN}

\section{Kondisi Awal}

Dari hasil wawancara terhadap sepuluh orang guru, peneliti memperoleh informasi bahwa semua guru (sepuluh orang) belum memahami secara matang kerangka penyusunan administrasi mengajar seperti RPP dengan menerapkan model-model pembelajaran, 10 orang yang memiliki dokumen standar proses (satu buah), hanya empat orang guru yang pernah mengikuti pelatihan pengembangan RPP dengan penerapan model-model pembelajaran, umumnya guru mengadopsi dan mengadaptasi RPP yang menerapkan model-model pembelajaran didalamnya, kebanyakan guru memahami cara menyusun RPP dengan penerapan model-model pembelajaran secara lengkap, mereka setuju bahwa guru harus menggunakan RPP dengan menerapkan model-model pembelajaran dalam melaksanakan proses pembelajaran yang dapat dijadikan pedoman dalam proses pembelajaran. Selain itu, kebanyakan guru memahami dengan komponen-komponen RPP yang menerapkan model-model pembelajaran secara lengkap.

Berdasarkan hasil observasi peneliti terhadap sepuluh RPP yang dibuat guru (khusus pada siklus 1), diperoleh data bahwa masih ada guru yang tidak melengkapi RPPnya dengan komponen dan sub-subkomponen RPP penerapan model pembelajaran tertentu, misalnya komponen indikator dan penilaian hasil belajar (pedoman penskoran dan kunci jawaban). Rumusan kegiatan siswa pada komponen langkah-langkah kegiatan pembelajaran masih kurang interaktif, inspiratif, dan sistematis.

Dilihat dari segi kompetensi guru, terjadi peningkatan dalam menyusun administrasi mengajar dari siklus ke siklus . Hal itu dapat dilihat pada lampiran rekapitulasi administrasi mengajar dengan berbagai model pembelajaran dari Siklus $1 \mathrm{ke}$ Siklus 2.

Tabel kondisi guru SDN 1 Kopang sesuai status kepegawaian tahun pembelajaran 2019/2020

\begin{tabular}{|c|l|c|c|}
\hline No & Kondisi & Jumlah & Keterangan \\
\hline 1 & PNS & 8 & \\
\hline 2 & Non PNS & 8 & \\
\hline 3 & GBS & - & \\
\hline \multicolumn{2}{|c|}{ Jumlah } & 16 & \\
\hline
\end{tabular}


Tabel kondisi guru SDN 1 Kopang sesuai tingkat pendidikan tahun pembelajaran 2019//2020

\begin{tabular}{|l|l|c|c|}
\hline No & \multicolumn{1}{|c|}{ Kondisi } & Jumlah & Ket \\
\hline 1 & Strata 1 (S1) / D4 & 14 & \\
\hline 2 & Diploma 3 (D3) & - & \\
\hline 3 & Diploma 2 (D2) & 2 & \\
\hline 4 & Diploma 1 (D1) & - & \\
\hline 5 & SLTA & - & \\
\hline \multicolumn{2}{|c|}{ Jumlah } & 16 & \\
\hline
\end{tabular}

Tabel kondisi guru SDN 1 Kopang sesuai tugas guru sesuai SK penugasan guru dari pemerintah

\section{A. Siklus 1}

\begin{tabular}{|c|l|c|l|}
\hline No & \multicolumn{1}{|c|}{ Kondisi } & Jumlah & \multicolumn{1}{|c|}{ Keterangan } \\
\hline 1 & Guru Pendidikan Agama Islam & 2 & SK Bupati Lombok Tengah \\
\hline 2 & Guru Kelas I & 2 & SK Bupati Lombok Tengah \\
\hline 3 & Guru Kelas II & 2 & SK Bupati Lombok Tengah \\
\hline 4 & Guru Kelas III & 2 & SK Bupati Lombok Tengah \\
\hline 5 & Guru Kelas IV & 2 & SK Bupati Lombok Tengah \\
\hline 6 & Guru Kelas V & 2 & SK Bupati Lombok Tengah \\
\hline 7 & Guru Kelas VI & 2 & SK Bupati Lombok Tengah \\
\hline 8 & Guru PJOK & 2 & SK Bupati Lombok Tengah \\
\hline \multicolumn{2}{|c|}{ Jumlah } & 16 & \\
\hline
\end{tabular}

Siklus pertama terdiri dari empat tahap yakni: (1) perencanaan, (2) pelaksanaan, (3) pengamatan, dan (4) refleksi seperti berikut ini.

\section{A. Perencanaan ( Planning )}

1. Membuat lembar wawancara pra observasi dan pasca observasi

2. Membuat format/instrumen penilaian administrasi mengajar

3. Membuat format rekapitulasi hasil penyusunan RPP penerapan modelmodel pembelajaran siklus 1 dan 2

4. Membuat angket guru tentang supervisi akademik dalam pelaksanaan pembelajaran

Tabel kondisi awal guru SDN 1 Kopang yang membuat administrasi mengajar tahun pembelajaran 2019//2020 (Senin, 15 juli 2019)

\section{(Siklus 1)}

\begin{tabular}{|c|l|c|c|c|c|c|c|c|}
\hline No & \multicolumn{1}{|c|}{ Nama } & Silabus & RPP & Prota & Prosem & DH & DN & Ket \\
\hline 1 & (Nama Kepasek) & $\checkmark$ & $\checkmark$ & $\checkmark$ & $\checkmark$ & $\checkmark$ & $\checkmark$ & f \\
\hline 2 & (Nama Guru) & $\checkmark$ & $\checkmark$ & $\checkmark$ & $\checkmark$ & $\checkmark$ & $\checkmark$ & f \\
\hline 3 & Tanda Tangan KS & $\checkmark$ & $\checkmark$ & $\checkmark$ & $\checkmark$ & $\checkmark$ & $\checkmark$ & f \\
\hline 4 & Tanda Tangan Guru & $\checkmark$ & $\checkmark$ & $\checkmark$ & $\checkmark$ & $\checkmark$ & $\checkmark$ & f \\
\hline 5 & Pengisian Perangkat & $\checkmark$ & $\checkmark$ & $\checkmark$ & $\checkmark$ & $\checkmark$ & $\checkmark$ & f \\
\hline
\end{tabular}

pe = Guru yang dipilih untuk mewakili semua guru yang ada

Pelaksanaan (Acting)

Pada awal siklus pertama administrasi mengajar yang dibuat para guru belum sesuai seperti keinginan peneliti. Hal itu dibuktikan dengan masih adanya komponen administrasi mengajar seperti 1) silabus, 2) RPP, 3) Prota, 4) Promes, 5) Daftar hadir (DH), dan 6) Daftar Nilai (DN) belum dibuat secara lengkap oleh guru.

\section{B. Pengamatan (Observasi)}

Hasil pengamatan pada siklus 1 dapat dideskripsikan berikut ini: Pengamatan dilaksanakan Senin, 16 Juli 2019, terhadap sepuluh orang guru. Semuanya menyusun administrasi mengajar, tapi masih ada guru yang belum melengkapi administrasi mengajarnya dengan komponen administrasi mengajar seperti 1) silabus, 2) RPP, 3) Prota, 4) Promes, 5) Daftar hadir (DH), dan 6) Daftar Nilai (DN). Hasil pengamatan dari enam belas (16) guru didapatkan sbb :

- Satu orang tidak melengkapinya dengan RPP

- Satu orang tidak melengkapinya dengan prota

- Dua orang tidak melengkapinya dengan promes

- Satu orang tidak melengkapinya Pengisian Daftar Hadir (DH)

- Satu orang tidak melengkapinya Pengisian Daftar Nilai (DN)

Selanjutnya mereka dibimbing dan disarankan untuk melengkapinya dengan pendekatan dialog kolaboratif

\section{Refleksi}


Kegiatan refleksi berupa renungan atau pertanyaan yang dapat dijadikan acuan untuk melangkah ke siklus 2, diantaranya :

1. Apakah selama ini guru sudah melengkapi semua administrasinya dengan lengkap ?

2. Apakah belum ada sosialisasi tentang perubahan atau pengembangan administrasi mengajar?

3. Apakah langkah yang telah diambil pada siklus 1 dapat menyelesaikan masalah administrasi mengajar guru ?

4. Apakah solusi yang ditawarkan peneliti dapat meningkatkan mutu pembelajaran ?

\section{Siklus 2}

Siklus ke 2 juga terdiri dari empat tahap yakni: (1) perencanaan, (2) pelaksanaan, (3) pengamatan, dan (4) refleksi. Hasil pengamatan pada siklus ke dapat dideskripsikan berikut ini: Pengamatan dilaksanakan Selasa, 30 Juli 2019, terhadap sepuluh orang guru. Semuanya menyusun administrasi mengajar, tapi masih ada guru yang belum sepenuhnya melengkapi komponen-komponen administrasi mengajar yang diperlukan, diantaranya :

- Dua orang tidak melengkapinya Daftar Nilai (DN)

Selanjutnya mereka dibimbing dan disarankan untuk melengkapinya dengan pendekatan dialog kolaboratif

Tabel kondisi akhir guru SDN 1 Kopang yang membuat administrasi mengajar tahun pembelajaran 2019/2020 (Senin, 29 Juli 2019)

Siklus 2

\begin{tabular}{|l|c|c|c|c|c|c|c|c|}
\hline No & Nama & Silabus & RPP & Prota & Prosem & DH & DN & Ket \\
\hline 1 & 1 & $\checkmark$ & $\checkmark$ & $\checkmark$ & $\checkmark$ & $\checkmark$ & $\checkmark$ & f \\
\hline 2 & 2 & $\checkmark$ & $\checkmark$ & $\checkmark$ & $\checkmark$ & $\checkmark$ & $\checkmark$ & \\
\hline 3 & 3 & $\checkmark$ & $\checkmark$ & $\checkmark$ & $\checkmark$ & $\checkmark$ & $\checkmark$ & \\
\hline 4 & 4 & $\checkmark$ & $\checkmark$ & $\checkmark$ & $\checkmark$ & $\checkmark$ & $\checkmark$ & $f$ \\
\hline
\end{tabular}

\section{PEMBAHASAN}

Penelitian Tindakan Sekolah dilaksanakan di SDN 1 Kopang terdiri atas empat puluh (16) guru, dan dilaksanakan dalam siklus 1 dan siklus 2. Sepuluh guru dianggap mewakili dari tiap mata pelajaran yang diwawancarai. Meskipun begitu semua guru tetap diwajibkan melengkapi administrasi mengajarnya. Semua guru tersebut menunjukkan sikap yang baik dan termotivasi dalam menyusun administrasi mengajar dengan lengkap. Hal ini peneliti ketahui dari hasil pengamatan pada saat melakukan wawancara dan bimbingan penyusunan administrasi mengajar.

Selanjutnya dilihat dari kompetensi guru dalam menyusun administrasi mengajar, terjadi peningkatan dari siklus 1 ke siklus 2 .

\section{Silabus}

Dari ke-16 guru yang telah membuat silabus hasilnya cukup baik, tidak ada satu pun guru yang tidak membuat silabus. Dengan kata lain $100 \%$.

Rencana Pelajsanaan Pembelajaran (RPP) Adanya peningkatan pembuatan RPP yakni 5 orang guru yang sebelumnya tidak membuat RPP, pada siklus 2 semuanya membuat RPP setelah berdialog dengan peneliti, dengan kata lain terjadi peningkatan sebesar 31,25\%

\section{Program Tahunan (Prota)}

Adanya peningkatan sebesar 12,5 \% dalam pembuatan prota terhadap ke-16 guru yang disupervisi. Jika pada siklus 1 terdapat 2 guru yang tidak membuat prota, maka pada siklus 2 semua guru sudah membuatnya setelah berdialog dengan peneliti.

\section{Program Semester (Prosem)}

Adanya peningkatan sebesar 31,25 \% dalam pembuatan prosem terhadap ke-16 guru yang disupervisi. Jika pada siklus 1 terdapat 5 guru yang tidak membuat prosem, maka pada siklus 2 semua guru sudah membuatnya setelah dilakukan wawancara dengan peneliti.

\section{Daftar Hadir (DH)}

Adanya peningkatan sebesar 25, \% dalam pembuatan daftar hadir terhadap ke-16 guru yang disupervisi. Jika pada siklus 1 terdapat 4 guru yang tidak membuat prosem, maka pada siklus 2 semua guru sudah membuatnya setelah dilakukan wawancara dengan peneliti.

\section{Daftar Nilai (DN)}

Adanya peningkatan sebesar $\mathbf{3 7 , 5} \%$ dalam pembuatan daftar nilai terhadap ke-16 guru yang disupervisi. Jika pada siklus 1 terdapat 6 guru yang tidak membuat prosem, maka pada siklus 2 semua guru sudah membuatnya setelah dilakukan wawancara dengan peneliti. Sedangkan hasil dari instrumen supervisi akademik ada pada semua guru

KESIMPULAN 
Berdasarkan hasil Penelitian Tindakan Sekolah (PTS) dapat disimpulkan sebagai berikut.

1. Bimbingan berkelanjutan dapat meningkatkan motivasi guru dalam menyusun administrasi mengajar dengan lengkap dan perencanaan mengajar melalui supervisi akademik sehingga menghasilkan pembelajaran yang lebih bermutu. Guru menunjukkan keseriusan dalam memahami dan menyusun administrasi mengajar apalagi setelah mendapatkan bimbingan pengembangan administrasi mengajar/ RPP dari peneliti sehingga terjadinya peningkatan rata-rata dalam penyusunan administrasi mengajar sebesar 27,91\%.

2. Kegiatan supervisi akademik dapat meningkatkan kompetensi guru dalam menyiapkan perencanaan pembelajaran yang pada akhirnya meningkatkan mutu pembelajaran. Hal itu dapat dibuktikan dari hasil observasi /pengamatan yang memperlihatkan bahwa terjadi peningkatan kompetensi guru dalam mengajar dari siklus ke siklus sehingga terjadinya peningkatan rata-rata dalam perencanaan pembelajaran sebesar $17,91 \%$

\section{SARAN}

1. Telah terbukti bahwa dengan bimbingan berkelanjutan dapat meningkatkan motivasi dan kompetensi guru dalam menyusun administrasi mengajar dan perencanaan pembelajaran. Oleh karena itu, peneliti menyampaikan beberapa saran sebagai berikut.

2. Motivasi yang sudah tertanam khususnya dalam penyusunan administrasi mengajar dan perencanaan pembelajaran hendaknya terus dipertahankan dan ditingkatkan.

3. Dokumen perencanaan pembelajaran hendaknya dibuat minimal 2 rangkap, satu untuk arsip sekolah dan satunya lagi untuk pegangan guru dalam melaksanakan proses pembelajaran.

\section{DAFTAR PUSTAKA}

Alfonso dkk., 1981 dan Weingartner, 1973. Instructional supervision is here in defined as: behavior officially designed by the organization that directly affects teacher behavior in such a way to facilitate pupil learning and achieve the goals of organizati

Suparlan 2005:99 Menjadi Kepala Sekolah Profesional. (Bandung: Remaja Rosdakarya, 2003). hlm.12

Surya Dharma 1972, Peran dan Fungsi Pengawas Sekolah/ Madrasah ... Hlm. 4 (Instrumen supervise Akademik dalam http://akhmadsudrajat.files.wordpr ess.com /2009/03/instrumensupervisi-akademik.pdf

Instrumen supervise Akademik dalam http://akhmadsudrajat.files.wordpr ess.com-supervisi akademik.pdf

M. Ngalimin Purwanto, Administrasi dan Supervisi Pendidikan, (Bandung: PT. Remaja Rosyda Karya, 2008). Cet Ke-18. Hlm. 76

Made Pidarta, Supervisi Pendidikan Kontekstual, (Jakarta: PT Rineka Cipta, 2009), Hlm. 3

Sergiovanni. 1987. Supervisi Pendidikan dan Pengajaran : Konsep, Pendekatan, dan Penerapan Pembinaan Profesional, (Malang: Rosindo, 2007) Edisi Revisi. Hlm. 73

Sergiovanni. 1987. Penilaian unjuk kerja guru dalam mengelola proses pembelajaran

Surya Dharma, Peran dan Fungsi Pengawas Sekolah/ Madrasah. Dalam Jurnal Tenaga Kependidikan Volume 3, No. 1, April 2008. Hlm. 4

Tim Dosen Administrasi Pendidikan UPI, Manajemen Pendidikan, (Bandung: ALFABETA, 2009). Hlm.311 